\title{
A NEW SPECIES OF WIDOW SPIDER (GENUS LATRODECTUS) FROM SOUTHERN AFRICA (ARANEAE: THERIDIIDAE).
}

\author{
By IAN R. Mackay \\ Harvard College, Cambridge, Mass.*
}

Introduction. Despite numerous names there are apparently only a few species of widow spiders (Levi 1959). The members of the genus Latrodectus are of considerable interest since their venom has a fraction specific to vertebrates, as well as a group of proteins specific to insects, their normal prey. Several new species have recently been discerned as a result of studying the habits of sympatric black widows (Levi i966, McCrone \& Levi 1964). Minor but consistent differences in the genitalia were found later. Also, Abalos (1962,) found four sympatric species of black widows in Argentina, with different habits and egg-sacs.

In this paper a new species is described from Rhodesia; the first sibling species of the cosmopolitan Brown widow (L. geometricus). This new species was first separated by the distinctive, smooth eggsacs (Fig. 9). The two species seem to occur together. The genitalia are distinct, in contrast to the sympatric $L$. revivensis, $L$. pallidus and L. mactans tredecimguttatus in Israel (Levi 1966).

I have not been able to match this new species to any of the previous descriptions from Africa, most of which are based on color variations of $L$. geometricus.

EGG-SACS The different egg-sacs (Fig. 9) first made me aware of the possibility of another species confused with L. geometricus. The egg-sacs of L. rhodesiensis are smooth, spherical and dirty white in color (pure white when first constructed). They are larger than the yellow, tufted cocoons of geometricus, with an external diameter of IO-18 mm (5-9 mm in egg-sacs of geometricus from Rhodesia). These smooth cocoons consist of an inner, pear-shaped, thin-walled $\mathrm{sac}$ - approximately half the diameter of the complete structure surrounded by a layer of fluffy threads.

HeMolympH In a search for other distinguishing characters I examined the hemolymph of the two species using electrophoresis, since McCrone ( 1967 ) separated sibling species of $L$. mactans by this

*Mail address: Museum of Comparative Zoology, Harvard College, Cambridge, Mass. 02138. 

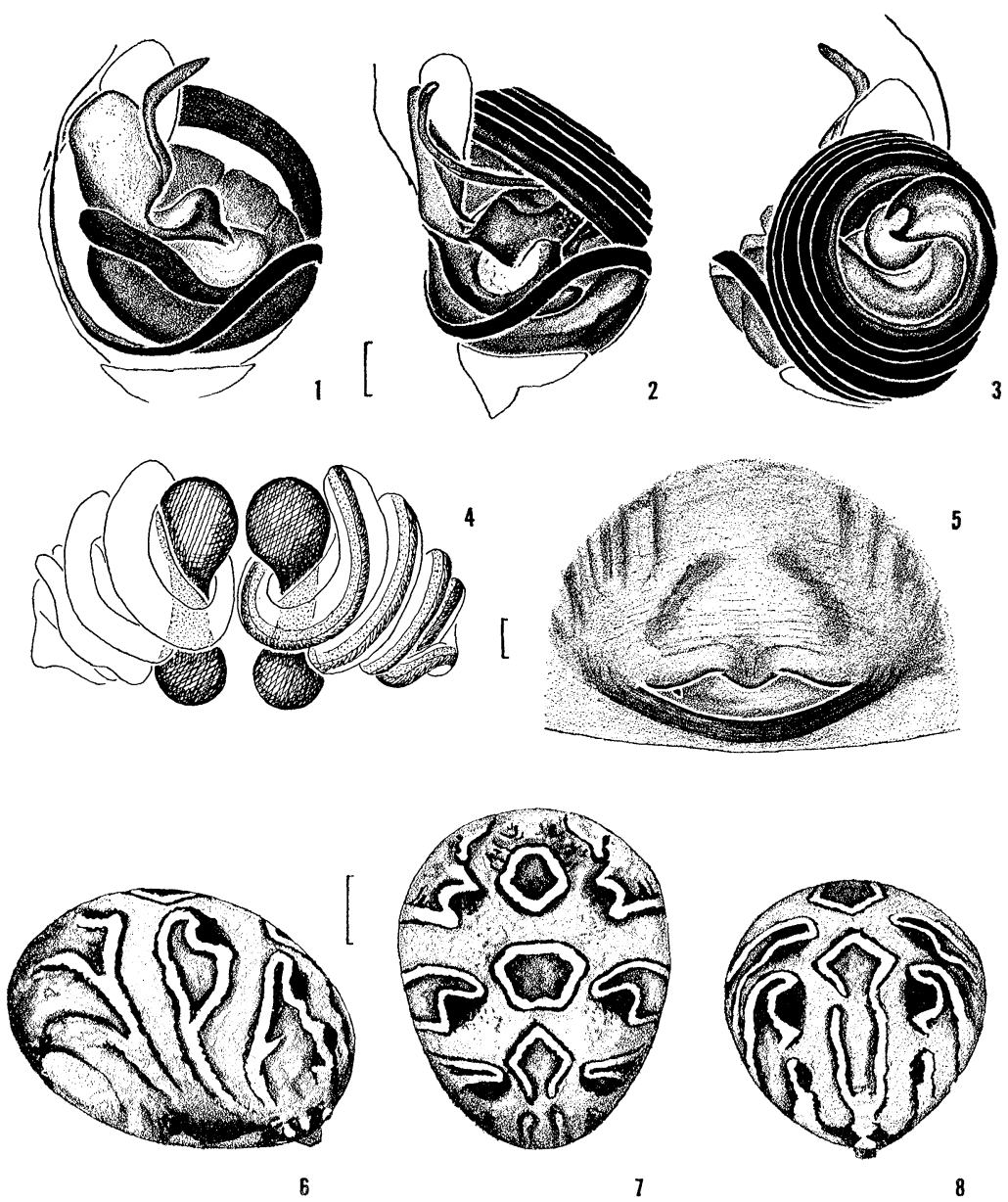

Figures 1-8. Latrodectus rhodesiensis, n.sp. Figs. 1-3, left male palpus. 1. mesal view; 2. ventral view; 3. lateral view. Figs. 415, epigynum. 4. dorsal view, cleared; 5. ventral view. Figs. 6-8, female abdomen. 6. lateral view; 7. dorsal view; 8. posterior view.

Scales: Figs. 1-5, $0.1 \mathrm{~mm}$; Figs. 7-9, $1 \mathrm{~mm}$. 


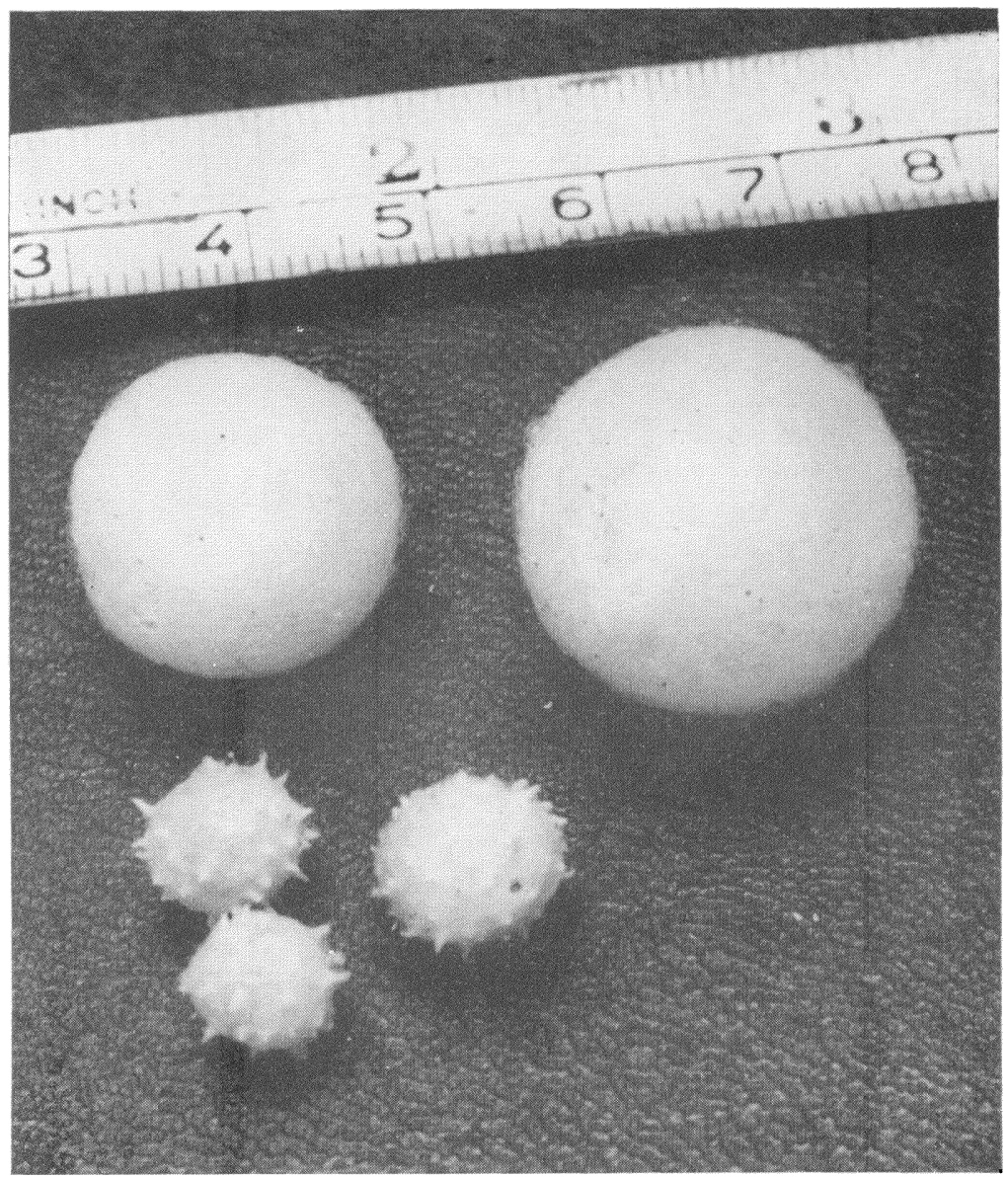

Figure 9. Egg-sacs of L. rhodesiensis (smooth) and L. geometricus (spiked). Lower scale in centimeters. 
method. The runs were made on Schleicher cellulose acetate strips in a Shandon Electric cell, with a Vokam SAE 276I power pack. Borate buffer ( $\mathrm{pH} 8.48$ ) was used and $150 \mathrm{~V}$ constant voltage at $3 \mathrm{ma}$ applied for several hours. The results to date indicate that there are differences, for example in the lowered mobility of the last band in geometricus (Fig. IO), but the method is too crude to permit accurate separation.

A difference in the color of the extracted hemolymph was also noted: that from geometricus was pale pink and from rhodesiensis the hemolymph was colorless.

Natural history The two species are found in the same habitat, often living within a meter of each other. No consistent differences have been noticed in the position of the retreat or in the web structure. A qualitative examination of the prey remains of both species has failed to show food preferences.

Differences have been seen in the breeding biology. The mean number of eggs per cocoon (in captivity) is different: $133.59 \pm$ 39.78 ( 29 cocoons) for geometricus; and $166.38 \pm 70.31$ (86 cocoons) for rhodesiensis. The diameter of the eggs is $0.9 \mathrm{I}-0.92 \mathrm{~mm}$ in geometricus and $0.92-0.96 \mathrm{~mm}$ in rhodesiensis. The color of the egg is different: those of rhodesiensis are pale yellowish flesh; while eggs of geometricus are dark pink. Kaston (1970), however, has noted eggs of different colors in the same cocoons of black widows. The cocoons of both species are parasitized by the larvae of Mantispa tenella (Neuroptera: Mantispidae). No consistent differences were discerned in preliminary observations of the postembryological development. Two series of young of each species were reared to the sixth instar (adult males and immature females) and showed no differences in pattern.

\section{Latrodectus rhodesiensis sp.n.}

Figures I-9

Types Male holotype, female paratype from Salisbury (Rhodesia), deposited in the Natal Museum, Pietermaritzburg (South Africa). Paratypes deposited in the British Museum (Natural History) and the Museum of Comparative Zoology.

Description. Similar in appearance to L. geometricus. Females apparently have similar measurements. The male measures: $2.5 \mathrm{~mm}$ total length. Carapace $1.2 \mathrm{~mm}$ long and $1.0 \mathrm{~mm}$ wide. First femur, $2.3 \mathrm{~mm}$; patella and tibia, $2.6 \mathrm{~mm}$; metatarsus, $2.6 \mathrm{~mm}$; tarsus 1.0 $\mathrm{mm}$. Second patella and tibia, $1.4 \mathrm{~mm}$; third, $0.9 \mathrm{~mm}$; fourth, I.7 $\mathrm{mm}$. 


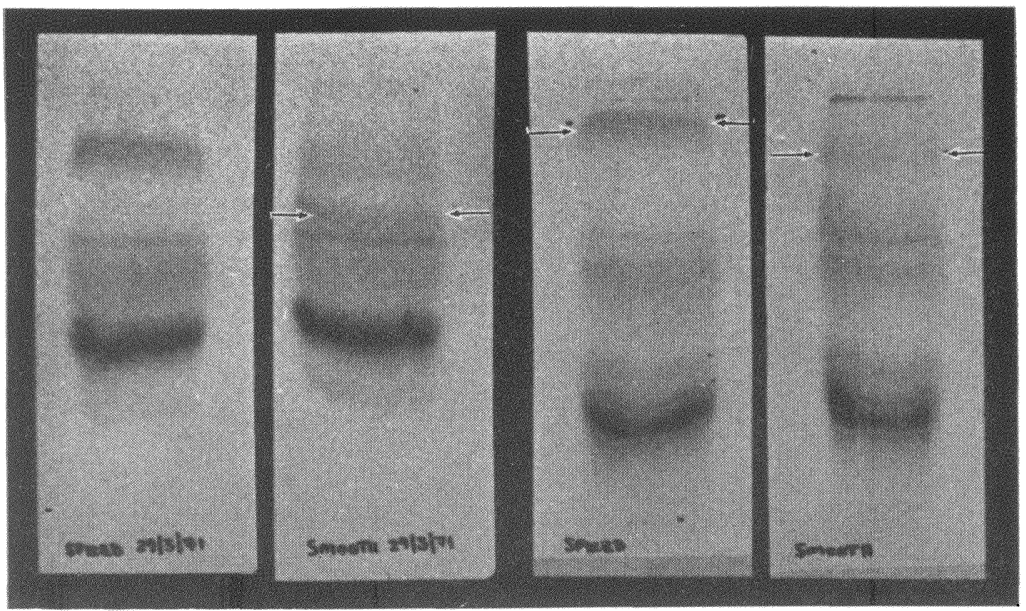

Figure 10. Electrophoresis plates of L. geometricus (1st and 3rd plates from left) and $L$. rhodesiensis (2nd and 4th plates). 1st and 2nd; $3 \mathrm{rd}$ and 4th plates run together. Differences noted by arrows.

Diagnosis The males are distinguished from $L$. geometricus by the additional coil of the embolus and by the lack of a spur on the conductor (Figs. I-3). The epigynum is much like that of geometricus. The spermathecae are more heavily sclerotised than in geometricus and the coils of the ducts extend antero-laterally beyond the spermathecae (Fig. 4). The inner line of the pattern of the female abdomen seems more distinct (Figs. 7, 8).

RECORDS Rhodesia: I have collected specimens of $L$. rhodesiensis in Salisbury. Smooth cocoons have been found in Kariba (G. Begg), Darwendale (IRM) and Bulawayo (IRM). I have collected $L$. geometricus in Salisbury and Umtali.

South Africa: J. Ledger (pers. comm.) collected a single female L. rhodesiensis in Walkerville (30 Km south of Johannesburg). G. Newlands has sent me specimens of $L$. geometricus from Pretoria (Transvaal), and Kroonstad and Boshof (Orange Free State).

Mozambique: D. Broadley collected a single female L. geometricus with egg-sacs $35 \mathrm{Km}$ south of Inchobe, on the new road to $\mathrm{NE}$ Mozambique.

Botswana: There is a single female L. geometricus in the MCZ collection from Tonota (D. Carmichael).

Acknowledgments I wish to thank my parents, Dr. R. Phelps, Mr. K. Coates-Palgrave and Mr. B. Lamoral for their help. Mr. 


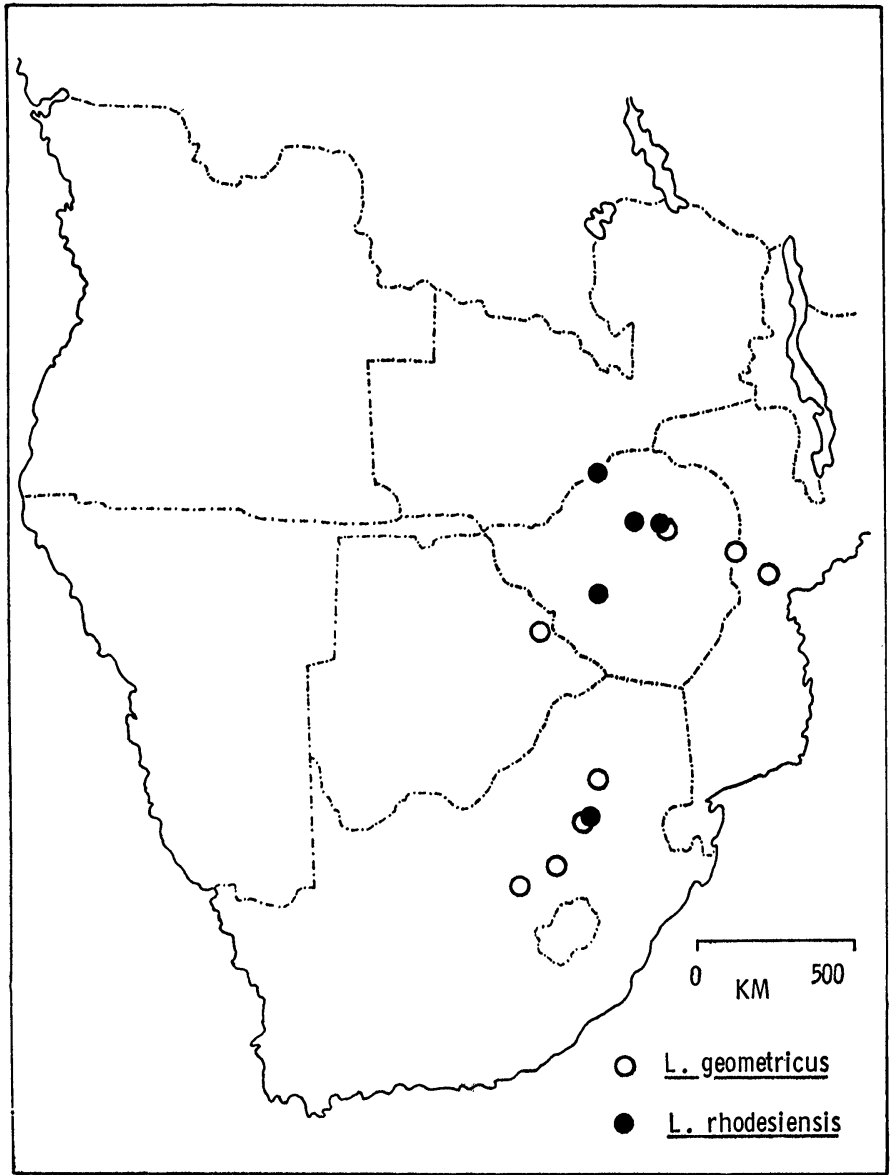

Map 1. Southern African records of $L$. rhodesiensis and $L$. geometricus. 
M. Oliver made available electrophoresis equipment and I am grateful for the photographic assistance of Messrs. P. Holland and K. Koths. Dr. A. Hesse kindly identified the cocoon parasites. I also wish to thank Mr. and Mrs. J. Coates-Palgrave for their hospitality and all persons who sent me specimens: Mr. G. Begg; Dr. D. Broadley; Messrs. B. Lamoral, J. Ledger and G. Newlands; and Dr. R. Smithers. I also wish to thank Professor H. W. Levi for his help and encouragement with all aspects of this work. The preparation of the manuscript and publication expenses were paid in part from National Institutes of Health Grant AI - I944 and NSF grant $\mathrm{GB}-3616$ I to $\mathrm{H}$. W. Levi.

Abalos, J. W.

\section{REFERENCES}

1962. The egg-sac in the identification of species of Latrodectus (Black widow spiders). Psyche 69 268-270.

KASTON, B. J.

1970. Comparative biology of American black widow spiders. Trans. San Diego Soc. Nat. Hist. 16 (3) 33-82.

LEVI, H. W.

1959. The spider genus Latrodectus. Trans. Amer. Microsc. Soc. 128 (1) 7-43.

1966. The three species of Latrodectus found in Israel. J. Zool. London 150 (4) 427-432.

McCrone, J. D.

1967. Biochemical differentiation of the sibling black widow spiders, Latrodectus mactans and L. variolus. Psyche 74(3) 212-217.

McCrone, J. D. And Levi, H. W.

1964. North American widow spiders of the Latrodectus curacaviensis group (Araneae: Theridiidae). Psyche 71(1) 12-27. 

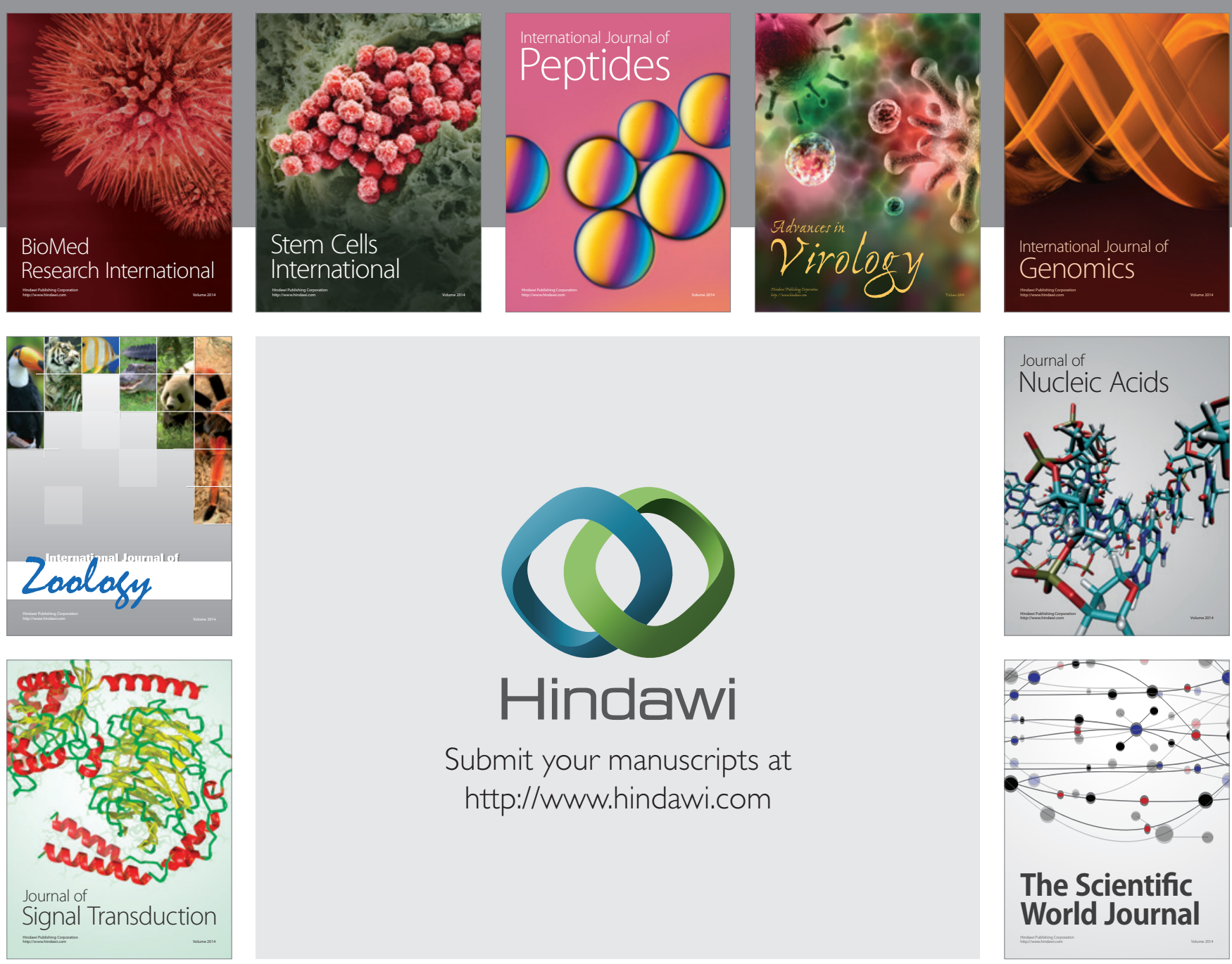

Submit your manuscripts at

http://www.hindawi.com
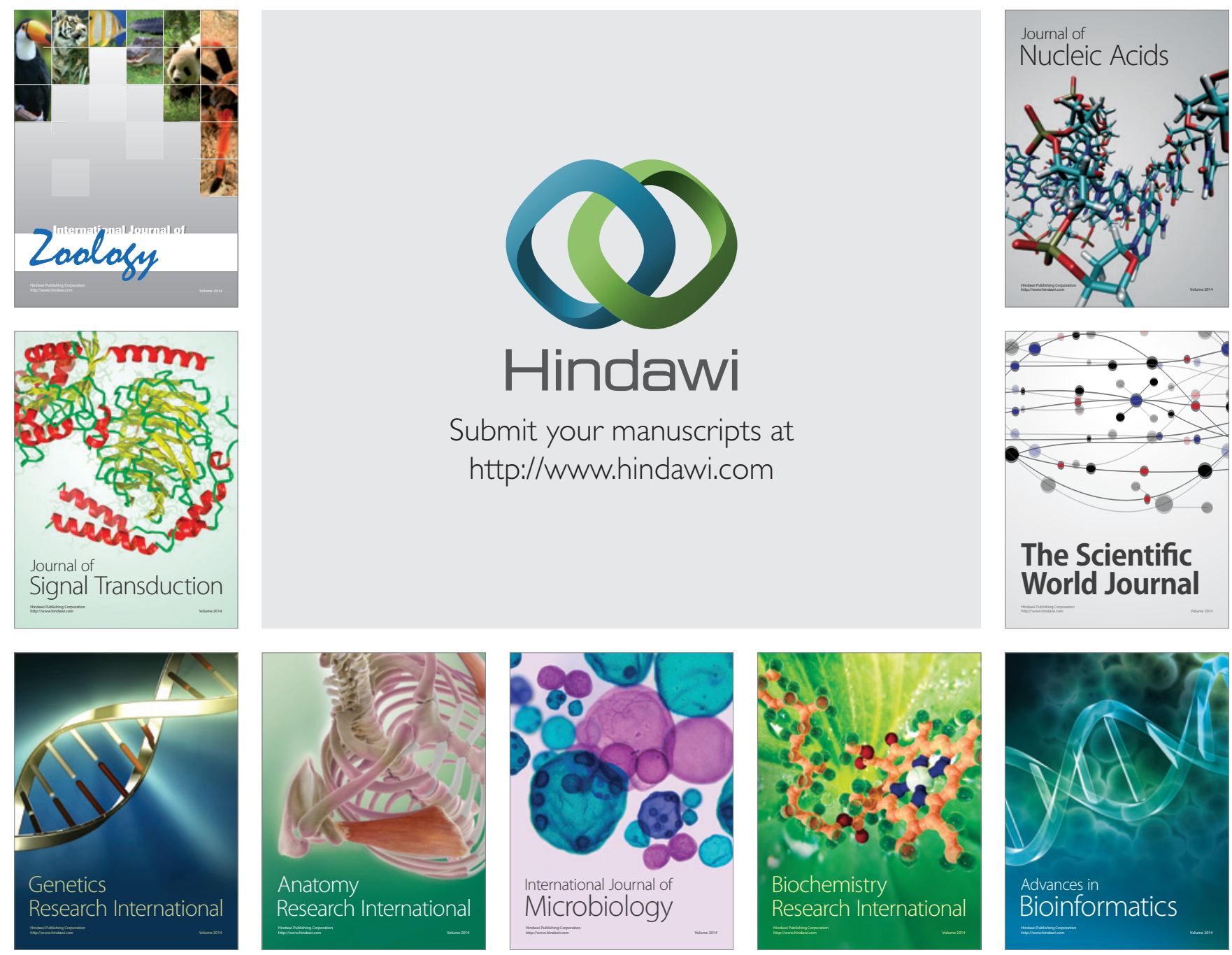

The Scientific World Journal
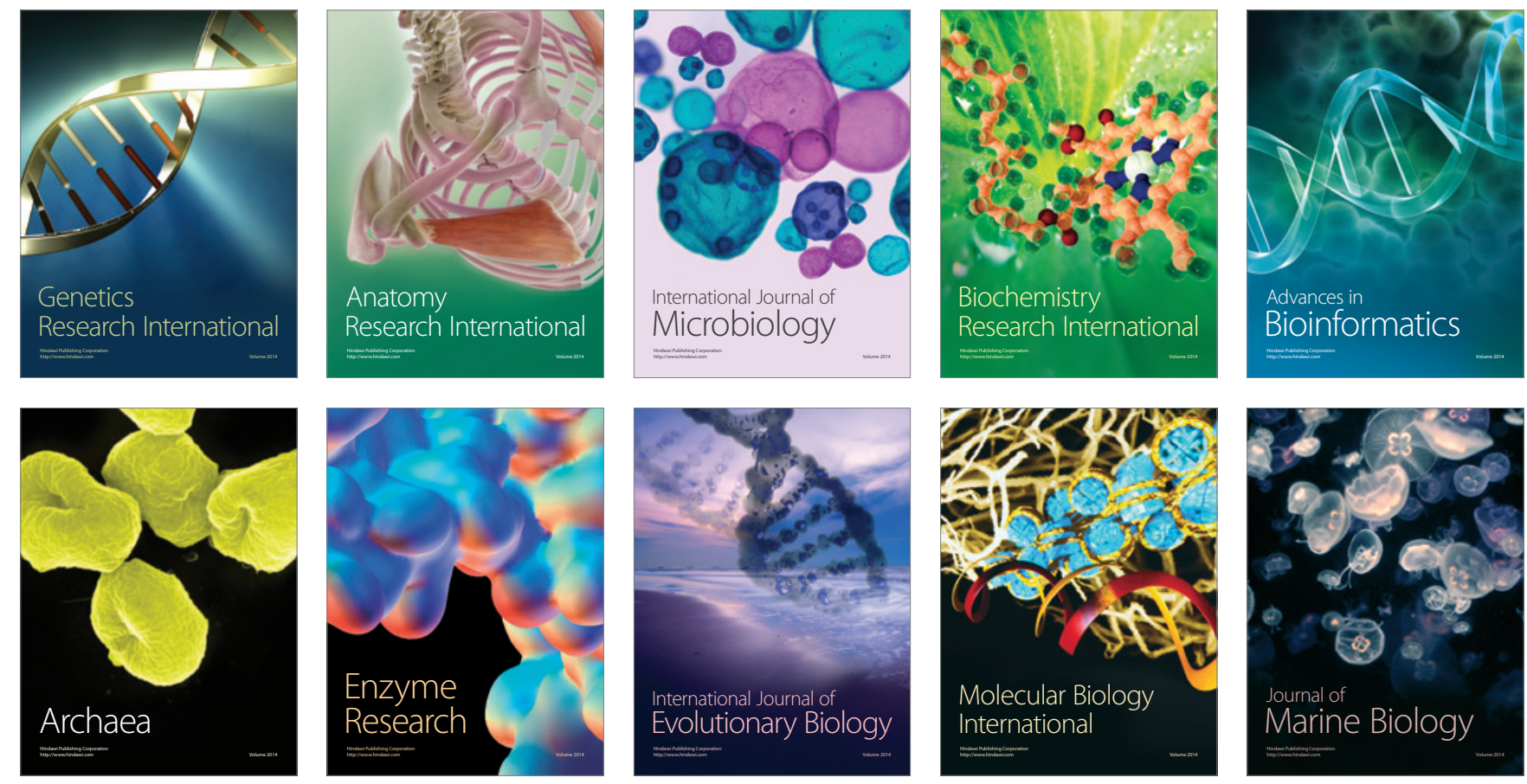